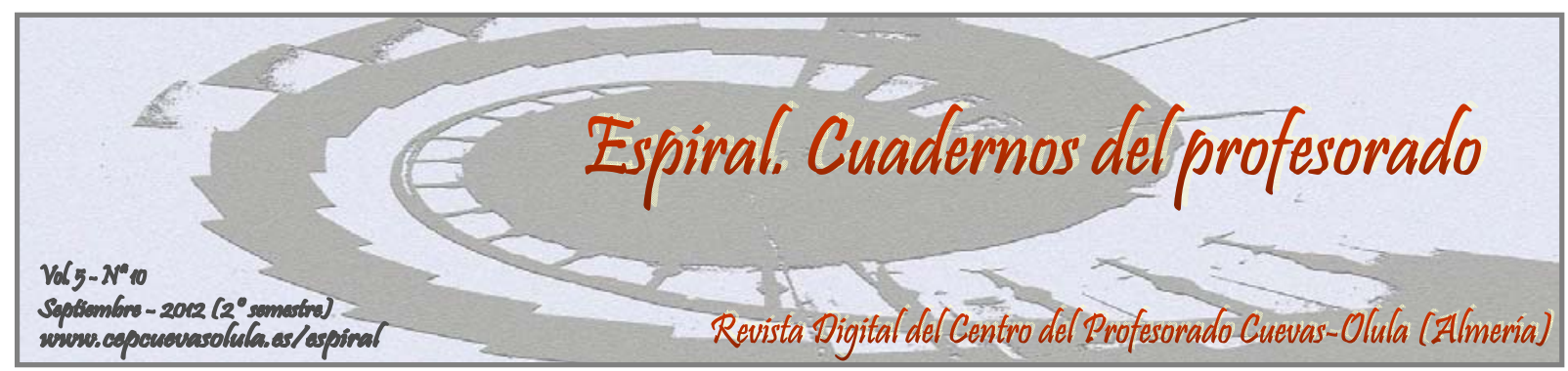

\title{
STARTING POINT TOWARDS BILINGUALISM IN HIGHER EDUCATION: RESULTS IN ENGLISH AT THE UNIVERSITY ENTRANCE TEST FROM A GENDER PERSPECTIVE
}

\author{
PUNTO DE PARTIDA HACIA EL BILINGÜISMO EN EDUCACIÓN SUPERIOR: \\ RESULTADOS DE INGLÉS EN LA PRUEBA DE ACCESO A LA UNIVERSIDAD \\ DESDE UNA PERPECTIVA DE GÉNERO
}

\author{
María del Mar Sánchez Pérez ${ }^{(1)}$, Francisco Manzano-Agugliaro ${ }^{(1)}$ \\ y Sagrario Salaberri Ramiro(1)
}

(1) Facultad de Humanidades, Universidad de Almería, España

(2) Escuela Superior de Ingeniería, Universidad de Almería, España

\begin{abstract}
The current level of internationalization of Spanish universities is demanding an increase in the command of foreign languages among students. Numerous Spanish universities are introducing in their syllabi courses taught in languages different from Spanish, mainly English, through different multilingual programmes. The present paper analyzes the results obtained for the English exam at the Spanish university entrance test (PAU) from 2002 to 2010 in order to study the students' language level before entering tertiary studies. We took a sample of 15897 students, 6454 men and 9443 women. Analytically processed data provide excellent qualitative comparisons between the two groups, showing the differences of both and contrasting results with the national trend. They also provide information about the specific factors that influence the outcomes of these types of tests, in contrast with certain gender stereotypes attributed to language performance. The present study reveals that, as a starting point for successful bilingual education in higher education, the results in English at the entrance examination to university should be on average at least two points above the current. This would only be possible by the increase of the number of hours devoted to language teaching as well as by the restructuring of the current language teaching system both in secondary and bachillerato.
\end{abstract}

Key words: Gender, University Access Exams, english, bachelor's degree.

RESUMEN: El nivel actual de internacionalización de las universidades españolas está demandando un aumento en el dominio de lenguas extranjeras entre los estudiantes. Numerosas universidades españolas están introduciendo asignaturas impartidas en lenguas diferentes del español en sus planes de estudio, principalmente en inglés, a través de diferentes programas multilingües. El presente trabajo analiza los resultados obtenidos en el examen de inglés de la prueba de acceso a la universidad (PAU) desde 2002 a 2010 con el fin de estudiar el nivel de idioma de los estudiantes antes de comenzar estudios superiores. Para ello se tomó una muestra de 15897 alumnos, 6454 hombres y 9443 mujeres. El análisis de estos datos permite excelentes comparaciones cualitativas entre ambos grupos, mostrando las diferencias en sus resultados y contrastando con la tendencia nacional. También proporciona información sobre los factores específicos que influyen en los resultados de este tipo de pruebas, a diferencia de los estereotipos de género atribuidos a las capacidades lingüísticas. Este estudio revela que, como punto de partida para el éxito de la enseñanza bilingüe en educación superior, los resultados de la prueba de inglés en el examen de ingreso a la universidad deberían situarse, al menos, dos puntos de media por encima de los actuales. Consideramos que esto sólo sería posible a través del aumento del número de horas dedicadas a la enseñanza de idiomas, así como a través de la reestructuración del sistema actual de enseñanza de idiomas, tanto en secundaria como en bachillerato.

Palabras clave: Género, Prueba de Acceso a la Universidad, Inglés, Bachillerato. 
Sánchez Pérez, M.M., Manzano-Agugliaro, F., y Salaberri Ramiro, S. (2012). Starting point towards bilingualism in higher education: results in english at the university entrance test from a gender perspective. Espiral. Cuadernos del Profesorado, 5(10), 3-15. Disponible en: http://www.cepcuevasolula.es/espiral.

Fecha de recepción: 27/03/2011

Fecha de aceptación: 24/05/2012
Enviar correspondencia a: fmanzano@ual.es

\section{1.- INTRODUCCIÓN}

In recent years, we have witnessed a continuous growth of interest and concern for the domain of languages different from the native ones. We have seen how programmes and projects related to language improvement have increased becoming more accessible to everyone. Many of these programmes are already present in Spanish public and private schools in both compulsory and noncompulsory levels (primary, secondary and bachillerato). The autonomous region of Andalusia prompted in 2005 the Plurilingualism Promotion Plan, an initiative by which different content subjects are taught in a different language, mainly English, French and German (Lorenzo, 2010).

With regard to universities, this trend is motivated on the one hand, by the new demands of the current knowledge-based society, and on the other, to the implementation of the European Higher Education Area (EHEA, 2010; Altbach \& Knight, 2007).

According to the EU, one of the challenges of the current society is to train students to master different languages to promote intercultural dialogue and a greater social cohesion and integration. The European Higher Education Area (EHEA), launched along with the Bologna Process in March 2010, was meant to 'ensure more comparable, compatible and coherent systems of higher education in Europe.' (EHEA, 2010). Its implementation addresses the mobility of students and staff all around the world to promote internationalization with the purpose of enhancing the improvement in quality and international competitiveness pursuing the employability opportunities of the European graduates. This mobility practices result in a mixture of nationalities in university classrooms where different foreign languages are usually introduced to encourage the participation and understanding of international students. These domestically oriented practices to promote internationalization at universities are what Nilsson (2003) refers to as 'Internationalization at Home' and it is gradually becoming a priority among Spanish higher education institutions. For this purpose, it is inevitably necessary to own a good command of at least one foreign language. In the case of Andalusian universities, some foreign languages - usually English - are increasingly being introduced through different immersion approaches (e.g. CLIL) in courses of very different knowledge areas (Rubio \& Hermosín, 2010).

In Spain, the implementation of this kind of programs suppose a major challenge due to the poor level of communicative competence in foreign languages owned by Spanish students (see data in European Commission 2006). In order to bridge this gap, many Andalusian universities have agreed that students registered at any of the official study programmes must certify, before the issue of the appropriate academic degree, and as general competence, the knowledge of a second language in accordance with the Common European Framework of Reference for Languages, CEFR (CE, 2001). This requirement is articulated under the Royal Decree 1393/2007 of 29 October, which establishes the ordering of official university education, and which requires the certification of B1 language level to obtain an official degree (BOE, 2007). This way, the knowledge of a foreign language becomes essential not only for obvious reasons, but it is currently a requirement to obtain many official degrees in Spain.

This current revolution on the attempt to approach the level of internationalization of European universities has led to plenty of studies on the ways to improve language competences in 
higher education. However, few data have been provided about the language level owned by students just before entering university.

The present study reveals that, as a starting point for successful bilingual education in university studies, the average mark of the entrance examination to university should be higher that the obtained in the recent past years. This would only possible by the introduction of more efficient immersion programmes that imply a restructuring of the current teaching methods both in Secondary and Bachillerato and an increase in the level of teacher training (Salaberri, 2010).

\section{English as Lingua Franca}

Although the promotion of the English language was not the specific purpose of the Bologna process, the creation of the EHEA has implicitly contributed to the growing Anglicisation of European universities (Smit, 2010). Authors such as Altbach and Knight (2007), Grimshaw (2007) or Van Damme (2001) agree on the evidence of the increasing hegemony of English in international teaching and research across the globe. This evidence is attested to by the literature on multilingualism in university language policies and in practices inside and outside classrooms (Moore, 2011).

This is the case of the Andalusian universities, and more specifically Almeria, where the main foreign language used in their plurilingual classrooms is English, although languages such as French and Italian are gradually trying to find a niche.

Figure 1 shows the percentage of foreign language choice in the district and period under study. There is a clear dominance of English versus other languages. French stands in second position, though at a great distance. Languages such as German or Italian are introduced in the most recent years.

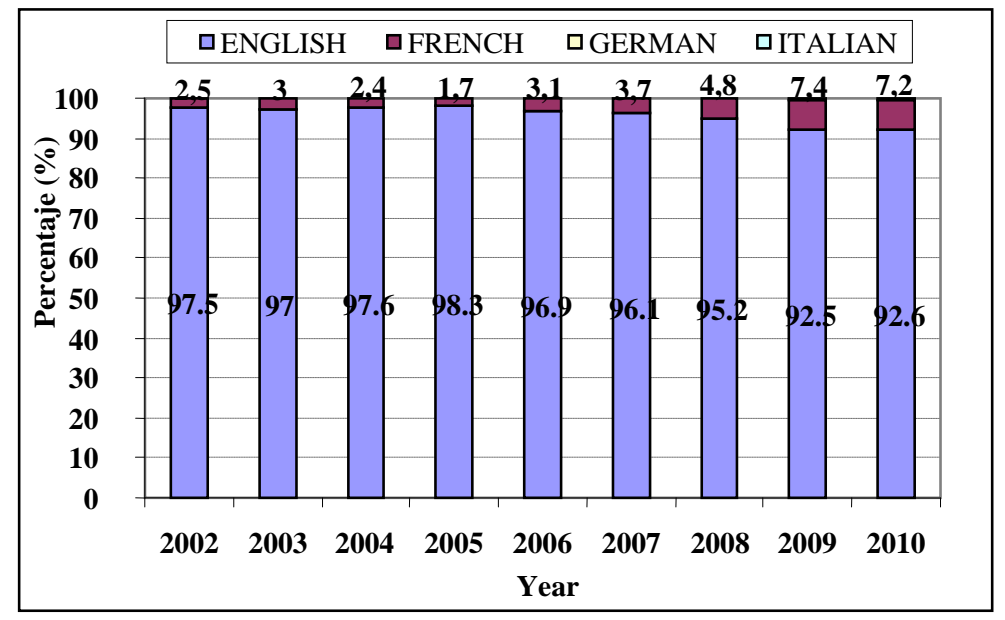

Figure 1. Rate of second language choice at PAU

In our study, we will focus on the English test, lingua franca of international communication, and the subject most commonly chosen.

\section{English at the Spanish educational system}

In spite of the fact that the introduction of the English language into classrooms is increasingly earlier, there are plenty of studies that reveal the poor level of English of Spanish students in comparison with the rest of European countries. According to the European Commission (2006), only 3 percent of the Spanish adult population think that dominates the English language correctly, although 36 percent say that can participate in a conversation in English, which stays well below the European average (50 percent) (Uribe, Gutíerrez \& Madrid, 2008).

Further studies reveal that 85 percent of Spanish households consider the command of English a necessity for their children as a complement that can be helpful in the future. However, a lack of 
motivation towards this issue is appreciated when students enter university and their language proficient is well below the desired (Ruiz, 2007).

Some experts attribute this problem to methodological differences existing between locations and the limited time devoted to language learning (Rodríguez \& Varela, 2004). For this reason, plenty of studies refer to the importance of introducing languages at earliest stages (Cenoz, 2003; Littlewood, 2001).

The Andalusian Education Act (2007) notes in its Chapter II the need to start learning at earlier stages certain fundamental matters such as a foreign language, among others. Section 53 of the same Act mentions the special attention that the teaching of foreign languages will receive during all educational stages (Junta de Andalucía, 2007).

\section{Bachillerato}

The Bachillerato corresponds to the post-compulsory secondary education stage. Unlike the latter, it is voluntary and lasts between 2 and 4 years. In Spain, it is regulated by the Decree 1467/2007. In the Autonomous Region of Andalusia, it is regulated by Decree 416/2008 and Order 5 of August 2008.

According to this regulation, the contents of foreign language subjects of Bachillerato are not set as a closed syllabus but as a set of communicative functions and associated skills, based on the Common European Framework of Reference for Languages (EFRL). This language policy programme provides a global scale of three levels (basic user [A], independent [B] and competent [C]), each subdivided into two, resulting in six levels. Then go, in order of increasing competence from A1 to C2. It is contemplated that the Bachillerato will help consolidate a competence level between A2 and B1. (Junta de Andalucía, 2012).

During this educational stage students must acquire sufficient intellectual and emotional maturity and knowledge and skills to develop as competent and responsible citizens. It provides access to Higher Level Vocational Training and University Studies upon the University Entrance Test (PAU) (Manzano, Martínez \& García, 2011).

There are four branches of Bachillerato with different itineraries guiding the student towards a progressive specialization. These types are: Arts, Humanities and Social Sciences, Technology and Natural Science and Health, (Spanish Ministry of Education, 2011).

The English subject stands at the common subjects group of this educational stage with a workload of 3 hours per week. It is compulsory and students must pass this subject to obtain their High School Diploma.

\section{2.- THE UNIVERSITY ENTRANCE TEST (PAU)}

The Spanish University Entrance tests (PAU, Prueba de Acceso a la Universidad) consists of a set of tests on the materials taught in the last year of Bachillerato. It takes place after the end of high school and before entering university. The joint evaluation of this test together with the two years of Bachillerato notes that the students are sufficiently prepared to achieve optimal use of the university studies chosen. The requirement to do the test is to hold a Higher School Diploma, obtained by passing the last course of Bachillerato. This test is valid for the access to all university degrees in Spain, and enrolling in a specific degree at a specific university will depend on the marks obtained (Manzano et al., 2011).

According to the most recent statistics in Spain, in the year 2010 a total of 244,737 students were registered at PAU and 207,464 passed - which corresponds to $84.8 \%$. Out of these data, 55.7\% were women. These figures confirm the trend that women are the predominant gender among the Spanish university students (Vázquez \& Manassero, 2009). 
The Regulation for the different University Entrance Tests in Spain dates back to Act 30/1974 of 24 July (BOE of 26 July) ${ }^{1}$ after which, the test articulated by Order of 9 January 1975, and was amended by Order of October 9, 1979 (Muñoz-Repiso et al., 1991a).

The test configuration has undergone continuous changes until the current PAU, launched in 2009-2010. Its regulatory framework is the Royal Decree 1892/2008, of 14 November (BOE of 24 November 2008), which regulates, at state level, the access conditions to official university degrees and the admission procedures to Spanish public universities. Part of these regulations are also the correction of errors of the Royal Decree 1892/2008, of November 14, published at BOE on Saturday, 28 March 2009 and EDU/1434/2009, Orders of 29 May and EDU/3242/2010 of December 9 by which the annexes of the Royal Decree 1892/2008 were updated and published at BOE No 135 of 4 June 2009 and 306 of December 17, 2010.

The new system for PAU consists of a general compulsory phase and a specific volunteer phase, in accordance with the speciality area taking during the Bachillerato. There are two options to choose and the length of each test is an hour and a half.

The foreign language test stands at the general phase, together with the rest of the common subjects for all the speciality areas: Spanish Language and Literature, History or Philosophy, and a specific subject of choice. The pass mark would be obtained with a 5, resulted from $60 \%$ of the average point grade in Bachillerato and $40 \%$ of the overall mark rate in this general phase - arithmetic average of the exercises-, with a minimum mark of 4 . Results in this phase have an indefinitely validity. In the specific phase, tests are on subjects from the speciality area chosen in Bachillerato and the student can decide the number of exercises to be performed, with a maximum of four, although only the two best will be considered. The expiration of the results in this specific phase is two years.

With regard to the second language exam, the most commonly taken is English, and less frequently French, German or Italian. Since the PAU reform in 2010, it is possible to take any of the abovementioned languages plus Portuguese.

\section{The English test}

The English test, of a written and practical nature, consists of two options A and B, which contains a reading exercise and three blocks of questions which assesses three different skills: comprehension, knowledge of vocabulary and grammar, and written expression. The reading text of each option has a length of between 250 and 280 words, and it is written in a non-specific language. They are taken from authentic sources, with a greater or lesser degree of adaptation. They can be informative, argumentative, descriptive or narrative (Junta de Andalucía, 2012).

As the rest of the tests, it lasts 1 hour and a half. Students are not allowed to use dictionaries or any other supporting material. The maximum score is 10 points. Of these, 4 are given to the text comprehension exercise, 3 to the use of English section, and 3 to written production.

As we mentioned before, the legislation regulating the contents of foreign language subjects in Bachillerato are a set of communicative functions and associated skills, based on the Common European Framework of Reference for Languages (EFRL). From this perspective, focused on the identification of skills and abilities leading to consolidate certain competences, the legislation emphasizes the need to plan the process of foreign language teaching as something inseparable from the integral development of students, which includes linguistic and communicative competences, learning-to-learn abilities, cultural, artistic and social skills, autonomy and personal initiative, among others. Within this context, languages should be taught to develop intercultural awareness, understanding of global issues and problems, and the acquisition of general learning strategies and training for life' (Junta de Andalucía, 2012).

This is also the objective in higher education, where the level of internationalization demands not only a command of at least a foreign language but a training background on global and intercultural issues.

\footnotetext{
${ }^{1}$ BOE, Boletín Oficial del Estado (Spanish Official Bulletin).
} 
The PAU is gradually adapting to this approach by including in its language tests exercises that contribute to demonstrate the ability to solve problems and produce results by the students under this perspective. The design of the foreign language test will be complete after the incorporation of a listening comprehension part foreseen by Royal Decree 1892/2008 of 14 November, which will be applicable from 2012.

\section{3.- GENDER STUDIES AT SPANISH UNIVERSITIES}

\section{Women at the Spanish Educational System}

Currently, the Spanish University System consists of 79 universities, 50 public and 29

private, scattered in 236 campuses. In the 2010-11 academic year 1.546.355 students were enrolled, of whom $54.2 \%$ were women. This gender dominance is extended to all levels of the Spanish university education (Spanish Ministry of Education, 2011).

The process of gradual incorporation of women into the education system is integrated into the framework of the revolution led by women from the late $19^{\text {th }}$ century and followed with greater force in the $20^{\text {th }}$ (Benso, 2003). Equal access to the Spanish universities was not until 1910, when the Count of Romanones, Minister of Public Instruction, signed the Royal Order in March 8, 1910 by which women were granted free enrolment in high education in the same conditions as men (Scanlon, 1987; Ballarín, 1989).

As stated in the Spanish National Statistics Institute, the first recorded data by gender on the Spanish university system dates back to 1998 . However, since the publication of the ratification in Spain of the Convention on the Elimination of All Forms of Discrimination against Women (CEDAW) by the UN in 1979 Spain was obliged to study statistically students disaggregated by gender (De Foronda, 2010).

\section{Gender differences in language competences}

Plenty of studies have been carried out about gender differences in language competences. First studies focused on the differences between men and women's language use (Lakoff, 1975). Since then, many studies have been developed to analyze the level of language performance according to gender at different educational levels. (Newman \& Handelman, 2008).

It has been widespread stated that women have more language abilities than men, and that they have to do, among other reasons, to biological and cognitive differences. According to some studies, girls start talking sooner than boys and they have better spelling and grammar skills, thus their language competences are considerably higher (Berninger et al., 2008; Kimura, 2000; Burman, Bitan \& Booth, 2008).

Further studies have been conducted on the level of attitude towards English classes from a gender perspective by which the girls have a more favorable attitude than boys (Uribe et al., 2008).

These data would make think that women should perform much better than men in English language tests.

However, studies on the entrance examination found that women usually have better academic performance at high school, but they get worse on punctual performance tests such as PAU (MuñozRepiso et al., 1991a; Cuxart, 2000, Manzano et al., 2011). According to some of these authors, school favours girls because of their greater ability to adapt to what is established and to their performance, which would lead them to get better marks from their teachers, but at 'the crunch time' they would show worse knowledge than men (Muñoz- Repiso et al., 1991b).

\section{4.- OBJECTIVES}

The present work intends to analyze the academic outcomes of the English exam at the Spanish University Entrance Test (PAU), comparing the results from a gender perspective, in order to ascertain the compliance of gender stereotypes in English academic performance. We tried to observe the level of a foreign language competence of a sample of Spanish students before starting their tertiary studies 
for a period in which the language competence has become more than a requirement in the Spanish higher education system.

We analyzed the results obtained in a specific and monolingual geographic area to compare them with the national tendency. The context selected was of interest due to the proliferation of bilingual programmes introduced in university syllabi, and the general poor language level in this region, which makes increase the concern on this matter among the university community.

The following variables were analyzed by gender: presence rate (PR) - students taking the exam -, pass rate (PS), grade point average (GPB), and distribution of GPB by academic years.

The present study intends to provide an overall view of the results obtained in the English exam at the Spanish University Entrance Test (PAU) for a period of 9 years - 2002 to 2010. Results will be studied from a gender perspective in order to establish qualitative comparisons between both groups as well as contrast results with preconceived stereotypes. The conclusions obtained may help reconsider the current educational model in order to achieve a better preparation of students' language competences before accessing tertiary studies.

\section{5.- MATERIALS AND METHODS}

To conduct this study, data from the University Entrance Test (PAU) in the district of Almería (SouthEast Spain) in the call for June were used. A whole 9-year period was selected, 2002-2010. These data only showed information about the total number of students and women, thus it was necessary to deduce data for men. Furthermore, data provided only absolute numbers; hence average data had to be calculated.

Although the language choice alternatives at the PAU have increased in the last few years, this study is restricted to the English exam, for being the language most commonly chosen, see figure 1.

The population under study consists of a total of 15897 students, 6454 men (M) and 9443 women (W), hence the female sample studied was be considerably higher. Table 1 shows the percentage of men and women registered at the English exam at PAU. It shows the average for the entire period 2002-2010. Table 1 shows the Percentage of men and women registered at the English exam at PAU, where $\mathrm{N}$ is the number of students analyzed, $\mathrm{T}$ is the percentage of students taking the exam, and $\mathrm{P}$ is the percentage of students passing the exam.

Table 1. Percentage of men and women registered at the English exam at PAU

\begin{tabular}{c|cccccc}
\hline \multirow{2}{*}{ Academic Year } & \multicolumn{4}{|c}{ MEN } & \multicolumn{3}{c}{ WOMEN } \\
\cline { 2 - 7 } & $\mathbf{N}$ & $\mathbf{T ~ ( \% )}$ & $\mathbf{P ~ ( \% )}$ & $\mathbf{N}$ & $\mathbf{T ~ ( \% )}$ & $\mathbf{P ~ ( \% ) ~}$ \\
\hline 2002 & 401 & 98.75 & 46.97 & 538 & 100.00 & 40.33 \\
2003 & 738 & 99.86 & 74.49 & 1083 & 99.63 & 68.77 \\
2004 & 733 & 99.59 & 77.26 & 1069 & 99.63 & 75.12 \\
2005 & 778 & 99.36 & 76.97 & 1201 & 99.58 & 69.82 \\
2006 & 702 & 99.00 & 66.19 & 1050 & 99.52 & 60.96 \\
2007 & 692 & 99.57 & 65.46 & 1047 & 99.62 & 62.03 \\
2009 & 746 & 99.60 & 58.41 & 1192 & 99.66 & 53.20 \\
2010 & 793 & 99.37 & 66.75 & 1150 & 100.00 & 63.39 \\
\hline TOTAL/AVERAGE & $\mathbf{6 4 5 4}$ & $\mathbf{9 9 . 4 4}$ & $\mathbf{6 7 . 7 6}$ & $\mathbf{9 4 4 3}$ & $\mathbf{9 9 . 7 0}$ & $\mathbf{6 3 . 2 6}$ \\
\hline
\end{tabular}

\section{6.- RESULTS}

\section{Presence Rate (PR)}

Table 1 shows no relevant differences in the rate of male and female students taking the exam (99.44\% 99.70\%), due to the compulsory nature of the foreign language exam at PAU. We can observe the high difference in the number of men enrolled at exam with regard to women. These data are in line to those for the general tendency of the rest of Spain, by which the number of women registering at 
university studies is usually higher that the number of men (INE, 2010). Within the context of our study, we can attribute this difference in both populations to the men's earlier access to the labour market and the beginning of the desired independence after the compulsory education in a period of economic prosperity. In a working market based mainly on the construction sector, commonly occupied by men, women are more focused on continuing their studies towards further preparation to face an increasing competitive job market. In fact, data show an increase in the number of men registering at the PAU as the current economic crisis approached.

As we mentioned before, there is a gender stereotype by which women usually perform better than men in language subjects due to reasons related to differences in biological and cognitive abilities. However, we can see from our data that this difference is not so evident, or it may be caused by different factors. It is observed as the pass rate for males during the whole period of study is slightly higher than for women, which contrasts to the previously mentioned theories.

Figure 2 shows the percentage of men and women taking the English exam. We can observe a clear continuity in the presence rate of women over the whole period. However we can see some differences in the presence rate of men, which coincide with the abovementioned periods of economic boom when many men left studies to start working. Notwithstanding, there is a considerably high presence rate at this test for both genders.

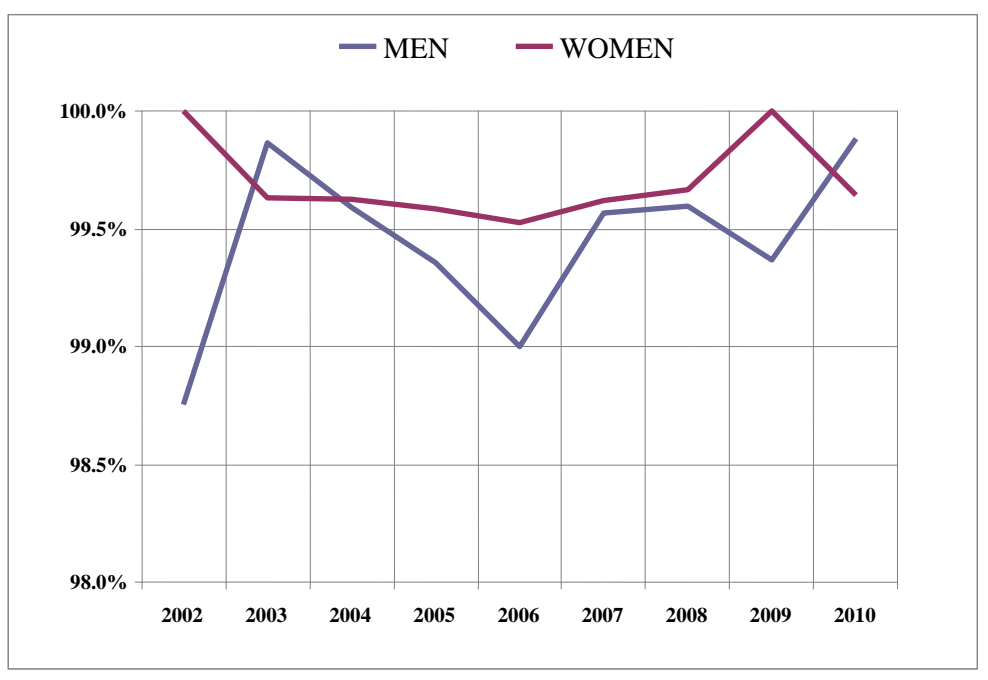

Figure 2. Presence rate (PR) by gender

\section{Pass rate (PS)}

Figure 3 shows how the pass rate has slightly increased along the period under study. In contrast to what we might think, it is observed that this pass rate remains higher for men during the whole period analyzed. This matches the previous theories which state that women usually have better academic performance at high school, but they get worse on these specific university entrance tests. (MuñozRepiso et al., 1991b; Cuxart, 2000; Manzano et al., 2011). We could attribute these results to the fact that men who decide to continue their studies instead of start working have a higher vocational attitude towards studies than women. 


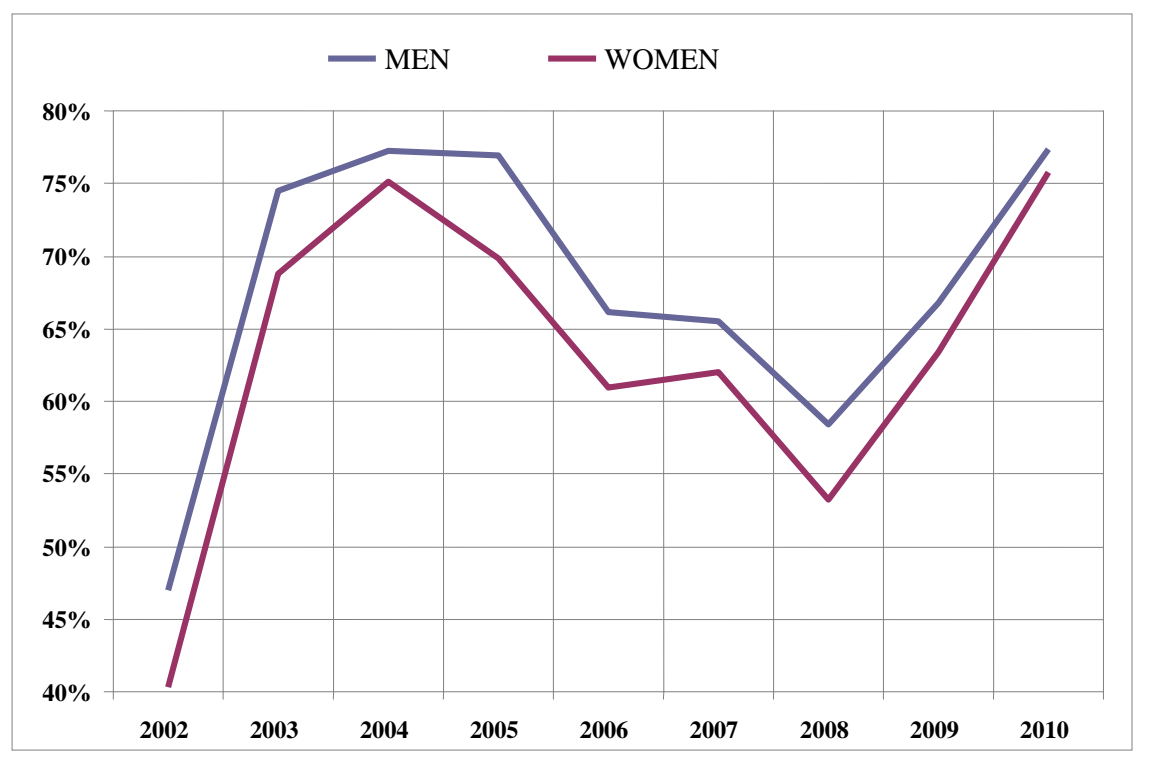

Figure 3. Pass rate (PS) by gender

\section{Grade Point Average (GPA)}

In this section, data relative to grade point average GPB) were analyzed. Figure 4 shows the grade point average (GPB) by gender during the period of study. It is remarkable that not only have men higher pass rates, but they also obtain higher results than women. Although there are more marked differences between men and women in the first half of the period analyzed, the trend in the last three years has been to improve the situation, becoming the last year analyzed the best performing in both sexes.

The last call studied, 2010, was the highest in the overall average rating and the most equaled between men and women -6.44 for men and 6.33 for women. This confirms that the current economic situation is fostering in students the motivation to get better results to enter the desired degrees that can ensure their labour future in the current highly competitive environment.

Figure 4. Pass rate (PS) by gender for the entire period (2002-2010)

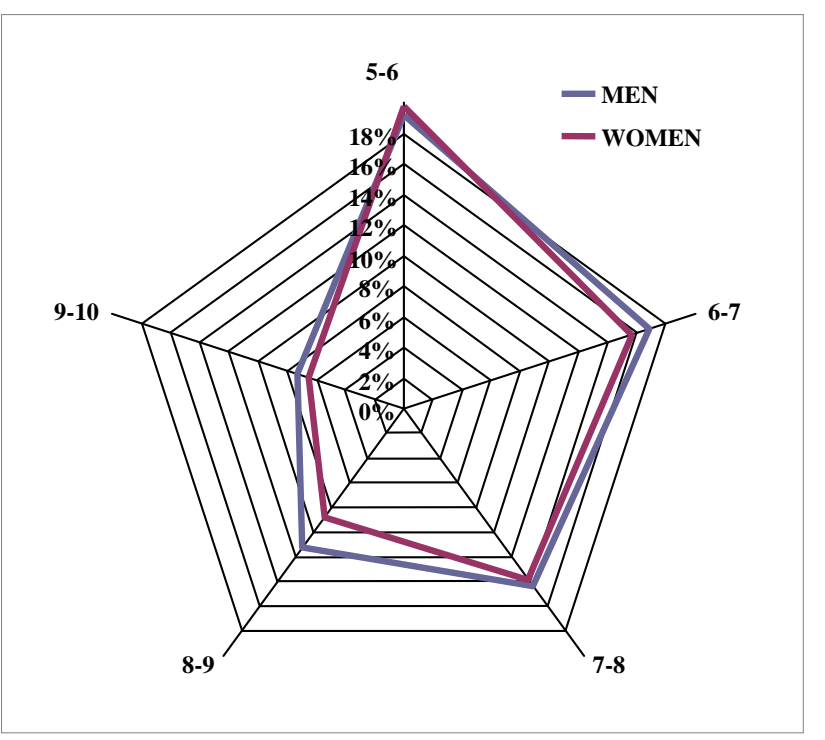

\section{Distribution of GPA by gender}

Figure 5 shows the average percentage for each grade rank with regard to the total for each gender. We can observe how women outnumber men in fail grades (0-5). There is an inflection point in the 56 rank in which men overcome women and stand over the second gender for the rest of grades. It is also remarkable the slight difference in favour of men in the two last ranks, which correspond to the highest marks (8-9; 9-10). This contrasts with the gender stereotype above mentioned. 
Figure 5. Grade Point Average by gender

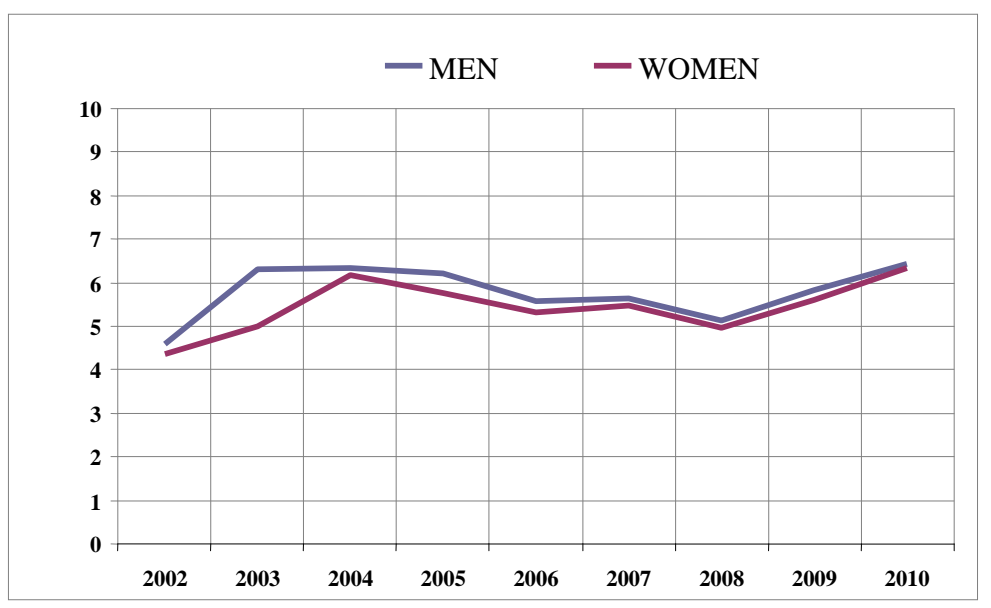

Figure 6. Grade Point Average distribution by gender during the whole period (2002-2010)

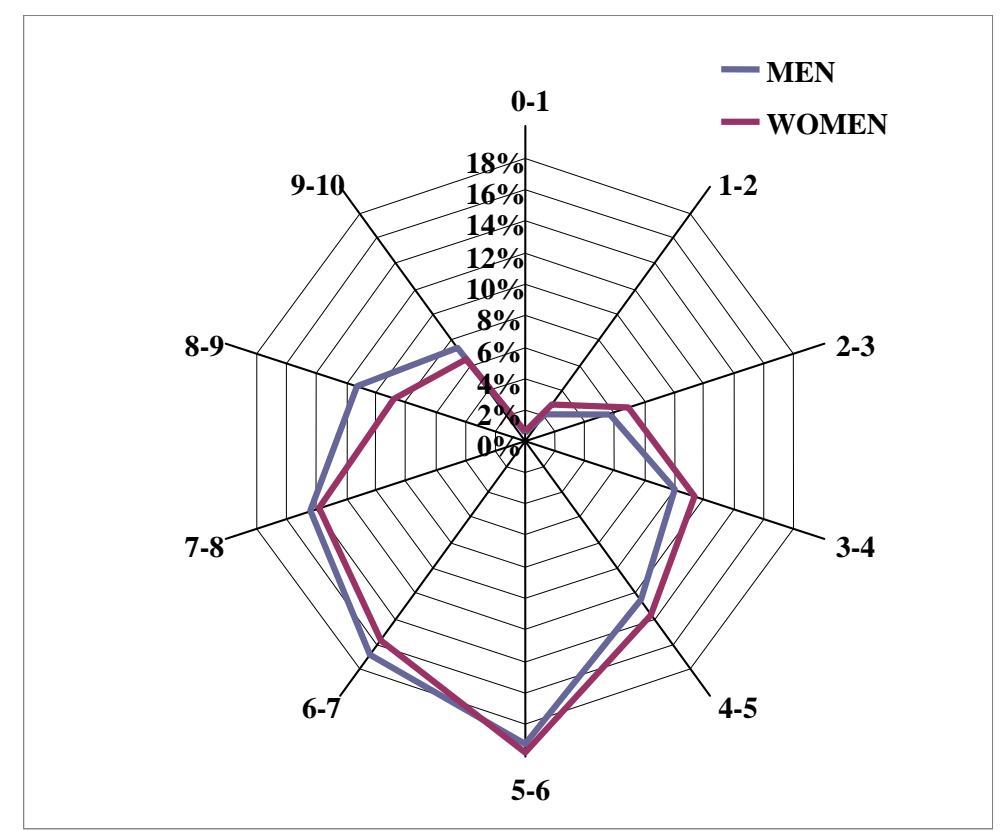

\section{7.- DISCUSSION}

The analysis of the results in English at the Spanish University Entrance Test (PAU) obtained in the last 9 years (2002-2010) in the Andalusian district of Almería show a 34\% fail rate in general, which stands above the European average. From these data we can deduce the need to increase the coordination between the contents of Bachillerato and the PAU to improve the results of the university entrance test.

With regard to gender, results show the same trend as the national one with higher presence rate for women with regard to men, but in our case the differences between both groups are smaller, and men outnumber women in the pass rate, contrary to what happens in the many other regions (Ministry of Education, 2011).

We should also highlight that our Spanish sample has been taken from a monolingual Community (Andalusia) where the opportunities to use a second language are scarce. Within this context, students may not find a stimulus in their environment that motivates the use of English. As 
the practice of that second language is usually limited to schools and universities, possibly the attitude of this group are directly related to the experiences they have in the classroom. In Spain the contact with native English speakers is very limited. (Uribe et al., 2008). The majority studies in the field of second language learning have been developed in countries where the presence of speakers of the language studied was very important (Canada or USA).

The increasing presence of English and other foreign languages in most European universities should make us reflect on the development of coherent educational policies that collect the knowledge and experience of English teachers and experts in the planning area (Lasagabaster, 2002). Caballero (2008) notes the regrettable situation in which there are still generations who subscribe the phrase 'I studied French / English for six years, but I am not able to speak three words together.' Thus, it would be convenient to consider a series of conditions that guarantee the quality of foreign language teaching, such as time spent, linguistic objectives, methodology and teacher training, among others (Cenoz, 2003).

Furthermore, students should be encouraged to know more deeply the community and the speakers of the second language. Studies have shown that the frequent contact seems to promote positive attitudes (Dörnyei, 2006; Dörnyei \& Csizér, 2005; Gardner, 2007). Activities such as study trips, exchanges or immersions through music, television or cinema can help understand the context where English learning is embodied (Uribe et al., 2008). Data have demonstrated that countries that use these types of resources are among the European states where citizens speak more than one language (European Commission, 2006).

For all these reasons, we should thus seriously reflect on the need to work on educational proposals, tutorial actions at a family and educational-centre level to aware students of the need to improve their language competences to success both in the increasing global and international environment offered by universities and in an increasingly global and competitive professional future.

\section{8.- CONCLUSIONS}

The main conclusions obtained after this study are, firstly, the imperious need of coordination between the language teaching in Bachillerato and the English tests at PAU in order to try to reduce the high failure rate in this subject as well as to address this test to the needs the students will have when entering tertiary studies.

With regard to the stereotype by which women usually perform better in language areas, our analysis reveals the opposite. Men have shown to have higher pass rates and better results than women, keeping on average above them in marks from 6 to 10 .

Contrary to the theories that support the higher language performance of women with regard to men due to biological and cognitive factors, our data show that there are other specific elements, such as socio-economic factors that condition the results obtained in language tests. In the context and period analyzed, we have seen how men outperform women due to vocational issues. As we mentioned before, the men's earlier access to the labour market after the compulsory education in a context of economic prosperity made men who decided to continue their studies instead of start working to be those with a higher vocational attitude towards studies than women, and thus, with better results. These results are in line with the findings from those authors who demonstrated the lower results of women with regard to men in punctual tests, such as PAU, despite their better performance in high schools.

This study reveals that, as a starting point for successful bilingual education in higher education, the results in English of the entrance examination to university should be on average at least two points above the current. If the average mark of all students is between 5.5 and 6 , in order to increase 2 points, an improvement of one third of the result obtained would be required. This would only be possible by the increase of the number of hours devoted to language teaching as well as by the restructuring of the current language teaching system both in secondary and bachillerato. 


\section{9.- REFERENCIAS BIBLIOGRÁFICAS}

Altbach, P.G. \& Knight, J. (2007). The internationalization of higher education: Motivations and realities. Journal of Studies in International Education, 11, 290-305.

Ballarín, P. (1989). La educación de la mujer española en el siglo XIX. Historia de la educación: Revista Interuniversitaria, 8, 245-260.

Benso Calvo, C. (2003). Exclusión, discriminación y resistencias. El acceso de la mujer al sistema educativo (1883-1930), in Jato Iglesias, E. and Iglesias da Cunha, L., Xénero e educación social, (pp. 57-78). Santiago de Compostela, Edicions Laiovento.

Berninger, V.W., Nielsen, K.H., \& Abbott, R. D., Wijsman, E., \& Raskind, W. (2008). Gender differences in severity of writing and reading disabilities. Journal of School Psychology, A B, 151-172.

BOE. (2007). REAL DECRETO 1393/2007, de 29 de octubre, por el que se establece la ordenación de las enseñanzas universitarias oficiales. Boletín Oficial de Estado. 30 octubre, 2007 [online acceded $11 / 01 / 2012]$.

Burman, D., Bitan, T, \& Booth, JR. (2008) Sex differences in neural processing of language among children. Neuropsychologia. 46(5), 1349-62.

Caballero, M. (2008). Las competencias bilingües como objetivo. Experiencias docentes. Cauce, Revista Internacional de Filología y su Didáctica, 31, 89-101.

Cenoz, J. (2003). El aprendizaje del inglés desde educación infantil: efectos cognitivos, lingüísticos y afectivos. Eduling, 1 [Online acceded: 20/12/2011] http://www.ub.es/ice/portaling/eduling/esp/n_1/cenoz-art.htm.

Council of Europe (CE). (2001). Common European Framework of Reference for Languages (CEFR). Learning, Teaching, Assessment. Strasbourg. Council of Europe.

Cuxart, A. (2000). Modelos estadísticos y evaluación: tres estudios en educación. Revista de Educación, 323, 369-394.

De Foronda, P.V. (2010). Estadística universitaria desagregada por sexos, estado de la cuestión para la Asociación Clásicas y Modernas. Investigación para la Asociación Clásicas y Modernas [Online acceded: 3/01/2011] http://www.ciudaddemujeres.com/articulos/IMG/pdf_Investigacion_CyM.pdf.

Dörnyei, Z. (2006). Individual differences in second language acquisition. AILA Review, 19, 42-68.

Dörnyei, Z. \& Csizér, K. (2005). 'The effect of intercultural contact and tourism on language attitudes and language learning motivation'. Journal of Language and Psychology, 24(4), 327-357.

EHEA (European Higher Education Area). Budapest-Viena Declaration of the EHEA. Viena-Bologna Policy Forum. March, 12, 2010 [Online acceded: 11/01/2012]. http://www.ehea.info/newsdetails.aspx?ArticleId $=59$

European Commission (2006). European and Languages. Special Eurobarometer. 237, Wave 63.4, TNS Opinion \& Social. [Online acceded:

15/01/2012]

http://www.ec.europa.eu/public opinion/archives/ebs/ebs_243_en .pdf.

Gardner, R.C. (2007). Motivation and second language acquisition. Porta Linguarum, 8, 5-25.

Grimshaw, T. (2007). Critical perspectives on language in international higher education. In: Hayden, M., Levy, J. \& Thompson, J. (eds.), The Sage Handbook of Research in International Education. (pp. 365-378). London Sage.

INE (Instituto Nacional de Estadistica) (2010). Boletín Informativo [Online acceded: 21/01/2012] http://www.ine.es/revistas/cifraine/cifine_ext0604.pdf.

Junta de Andalucía (2007). Presidencia. Ley 17/2007, de 10 de diciembre, de Educación de Andalucía (LEA). BOJA 252. 26 december 2007.

Junta de Andalucía (2012). Directrices y orientaciones generales para las pruebas de acceso a la universidad. Lengua Extranjera Inglés. Distrito Único Andaluz. Consejería de Innovación y Ciencia. Junta de Andalucía. $\quad$ [Online $\quad$ acceded: 19/01/2012]. http://www.juntadeandalucia.es/economiainnovacionyciencia/sguit/paginas/distrito/examenes_sel_m25/ criterios_selectividad/criterios_sel_ingles.pdf

Kimura, D. (2000). Sex and cognition. Cambridge, MA: A Bradford Book. The MIT Press.

Lakoff, R. (1975). Language and woman’s place. New York: Harper Colophon Books.

Lasagabaster, D. (2002). The role of instrumental and integrative attitudes in a multilingual context. II Simposio Internacional del Bilingüismo. Victoria-Gasteiz: Universidad del País Vasco. 
Littlewood, W. (2001). Student's attitudes to classroom English learning: a cross-cultural study. Language Teaching Research, 5(1), 3-28.

Lorenzo, F. (2010). CLIL in Andalusia, in D. Lasagabaster \& Y. Ruiz de Zarobe, CLIL in Spain. Implementation, Results and Teacher Training (pp. 2-27). Cambridge Scholars Publishing. Newcastle.

Manzano, F., Martínez, J., \& García, A. (2011). Las Asignaturas de Ciencias en las Pruebas de Acceso a la Universidad: Perspectiva de Género. Espiral. Cuadernos del Profesorado, 4(8), 3-12.

Moore, E. (2011). Plurilingual interaction at a Catalan university doing internationalization: Context and Learning. PhD Thesis. Departament de Didàctica de la Llengua i la Literatura, i de les Ciènces Socials. Universitat Autònoma de Barcelona.

Muñoz-Repiso Izaguirre, M., Muñoz Vitoria, F, Palacios Gómez, C., Valle López, J., \& Escobar Fernández, M.C. (1991a). Introducción. In M. Muñoz-Repiso Izaguirre, F. Muñoz Vitoria, C. Palacios Gómez, J. Valle López \& M., Escobar Fernández. Las calificaciones en las pruebas de aptitud para el acceso a la universidad. (pp. 7-21). Madrid: Centro de Publicaciones del Ministerio de Educación y Ciencia: C.I.D.E.

Muñoz-Repiso Izaguirre, M., Muñoz Vitoria, F., Palacios Gómez, C., Valle López, J.M. \& Escobar Fernández, M.C. (1991b). Resultado según el sexo de los alumnos. En M. Muñoz-Repiso Izaguirre, F. Muñoz Vitoria, C. Palacios Gómez, J.M. Valle López \& M.C. Escobar Fernández. Las calificaciones en las pruebas de aptitud para el acceso a la universidad. (pp. 103-115). Madrid: Centro de Publicaciones del Ministerio de Educación y Ciencia: C.I.D.E.

Newman, G., \& Handelman, P. (2008). Gender differences in Language use: An Analysis of 14,000 Text samples. Discourse Processes, 45, 211-236.

Nilsson, B. (2003). Internationalization at Home from a Swedish perspective. Journal of Studies in International Education, 7, 27-40.

Rodríguez López, B., \& Varela Méndez, R. (2004). Models of teaching foreign languages to young children. Didáctica (Lengua y Literatura), 16, 163-175.

Rubio, F., \& Hermosín, M. (2010). Implantación de un programa de plurilingüismo en el espacio europeo de educación superior: Análisis de contexto y detección de necesidades. XXI, Revista de Educación, 12, 107-128.

Ruiz Garrido, M. (2007). Teaching and learning English for business communication: a case in Spain. Business Communication Quarterly, 70(1), 74-79.

Salaberri, M.S. (2010). Teacher Training Programmes for CLIL in Andalusia. In D. Lasagabaster \& Y. Ruiz de Zarobe, CLIL in Spain. Implementation, Results and Teacher Training. (pp. 140-159). Cambridge Scholars Publishing. Newcastle.

Scanlon, G.M. (1987). La mujer y la instrucción pública: de la ley Moyano a la II ${ }^{a}$ República. Historia de la Educación: Revista Interuniversitaria, 6, 193-208.

Smit, U. (2010). English as a Lingua Franca in Higher Education: A Longitudinal Study of Classroom Discourse. Berlin: Mouton de Gruyter [Online acceded: 10/01/2012].

http://www.boe.es/boe/dias/2007/10/30/pdfs/A44037-44048.pdf

Spanish Ministry of Education (2011). Datos y Cifras del Sistema Universitario Español. Curso 2010-11[Online acceded:

10/01/2012].

http://www.educacion.gob.es/dctm/ministerio/educacion/universidades/estadisticasinformes/novedades/ 2011-datos-cifras-10-uv.pdf?documentId=0901e72b809384a4

Uribe, D., Gutiérrez, J., \& Madrid, D. (2008). Las actitudes del alumnado hacia el aprendizaje del inglés como idioma extranjero: estudio de una muestra en el sur de España. Porta Linguarum. 10, 85-100.

Van Damme, D. (2001). Higher education in the age of globalization: The need for a new regulatory framework for recognition, quality assurance and accreditation. Paper presented at the UNESCO Expert Meeting, Paris, September 2001.

Vázquez, A. \& Manassero, A. (2009). Patrones actitudinales de la vocación científica y tecnológica en chicas y chicos de secundaria. Revista Iberoamericana de Educación, 50(4), 1-11

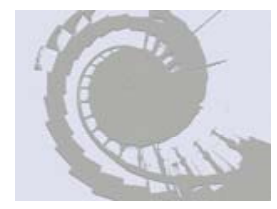

